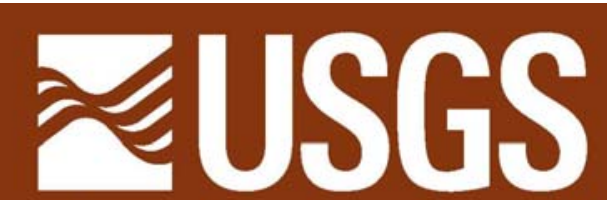

science for a changing world

\title{
Quality of Economically Extractable Coal Beds in the Gillette Coal Field as Compared With Other Tertiary Coal Beds in the Powder River Basin, Wyoming and Montana
}

By Margaret $S$. Ellis

U.S. Geological Survey Open-File Report 02-174 2002

U.S. DEPARTMENT OF THE INTERIOR

U.S. GEOLOGICAL SURVEY

This report is preliminary and has not been reviewed for conformity with U.S. Geological Survey editorial standards and stratigraphic nomenclature. Any use of trade names is for descriptive purposes only and does not imply endorsement by the U. S. Geological Survey. 


\section{Contents}

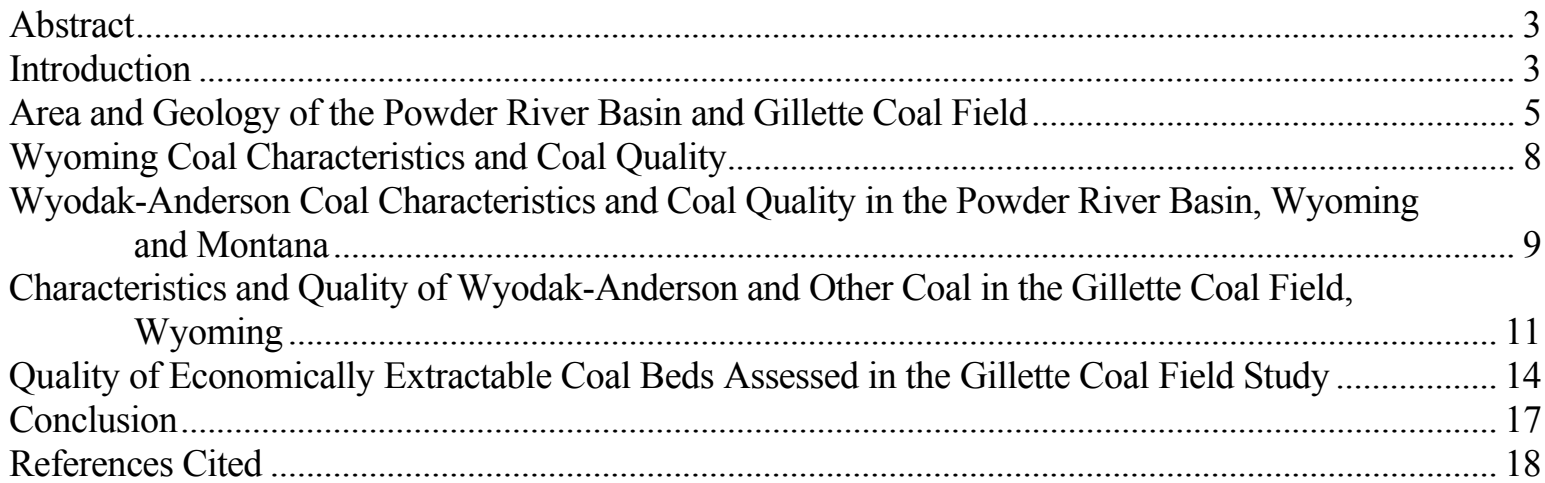

\section{Figures}

Figure 1. Map of the Powder River Basin, Wyoming and Montana, showing the basin axis,

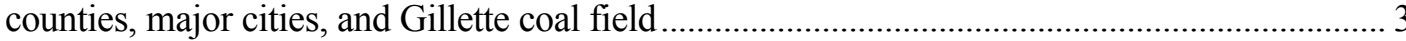

Figure 2. Location of mines in the Gillette coal field ......................................................................... 4

Figure 3. Map showing generalized geology in the part of the Powder River Basin around the Gillette coal field 5

Figure 4. Map showing the location of stratigraphic cross sections through the northern, middle,

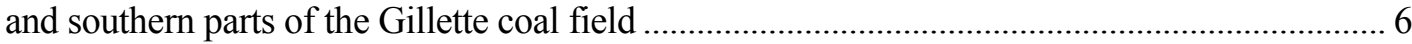

Figure 5. West to east structural cross section through the northern part of the Gillette coal field ......... 7

Figure 6. West to east structural cross section through the middle part of the Gillette coal field............ 7

Figure 7. West to east structural cross section through the southern part of the Gillette coal field ......... 8

Figure 8. Map showing locations in the Gillette coal field where samples from the WyodakAnderson coal zone were collected for coal quality analyses.

\section{Tables}

Table 1. Summary of the apparent rank and calorific value of mined coal from coal fields in Wyoming

Table 2. Designation of low, medium and high categories for total sulfur content and ash yield in coal, as defined in Wood and others, 1983

Table 3. Coal quality summary data for Wyodak-Anderson coal in the Powder River Basin, Wyoming and Montana

Table 4. Coal quality summary data using weighted averages, one value for each parameter at each data point location, for Wyodak-Anderson coal in the Gillette coal field

Table 5. Proximate, ultimate and calorific values using all sample analyses, more than one sample at each data point location, from coal beds in the Wyodak-Anderson coal zone in the Gillette coal field.

Table 6. Trace element content of coal samples from beds in the Wyodak-Anderson coal zone in the Gillette coal field

Table 7. Summary of coal quality and production of coal from mines in the Gillette coal field supplied to coal-fired power plants in 1999.

Table 8. Proximate and ultimate analyses and calorific values of economically extractable coal in the Gillette coal field 
Table 9. Values for potentially hazardous air pollutant trace elements in economically extractable coal in the Gillette coal field.

Table 10. Comparison of coal quality of the Wyodak-Anderson coal in the Powder River Basin and in the Gillette coalfield (Flores and others, 1999; Ellis and others, 1999), and of the economically extractable coal beds and the Upper Wyodak coal bed in the Gillette coal field. 


\begin{abstract}
The Powder River Basin, and specifically the Gillette coal field, contains large quantities of economically extractable coal resources. These coal resources have low total sulfur content and ash yield, and most of the resources are subbituminous in rank. A recent U.S Geological Survey study of economically extractable coal in the Gillette coal field focused on five coal beds, the Wyodak rider, Upper Wyodak, Canyon, Lower Wyodak-Werner, and Gates/Kennedy. This report compares the coal quality of these economically extractable coal beds to coal in the WyodakAnderson coal zone in the Powder River Basin and in the Gillette coal field (Flores and others, 1999) and other produced coal in the Gillette coal field (Glass, 2000). The Upper Wyodak, Canyon, and Lower Wyodak/Werner beds are within the Wyodak-Anderson coal zone. Compared with all coal in the Wyodak-Anderson coal zone, both throughout the Powder River Basin and just within the Gillette coal field; the thick, persistent Upper Wyodak coal bed in the Gillette coal field has higher mean gross calorific value $(8,569 \mathrm{Btu} / \mathrm{lb})$, lower mean ash yield (5.8 percent), and lower mean total sulfur content ( 0.46 percent).
\end{abstract}

\title{
INTRODUCTION
}

The U.S. Geological Survey (USGS) has recently conducted a study of economically extractable coal in the Gillette coal field, in the Wyoming part of the Powder River Basin (fig. 1). The study, concentrates on those coal beds that are most likely to be mined given such considerations as coal quality, coal thickness, stripping ratio, land use, environmental and technologic restrictions, and the economics of mining, transport, and current market value. Detailed information on other recent USGS studies, which used similar criteria for determining economically extractable coal in selected study areas, can be found in publications by Molnia and others, 1997, and Osmonson and others, 2000. A major factor in determining coal development potential is coal quality, because if the coal has high sulfur content, high ash yield, or certain trace element content, it may require cleaning and/ or processing before it could be utilized, which may make the coal

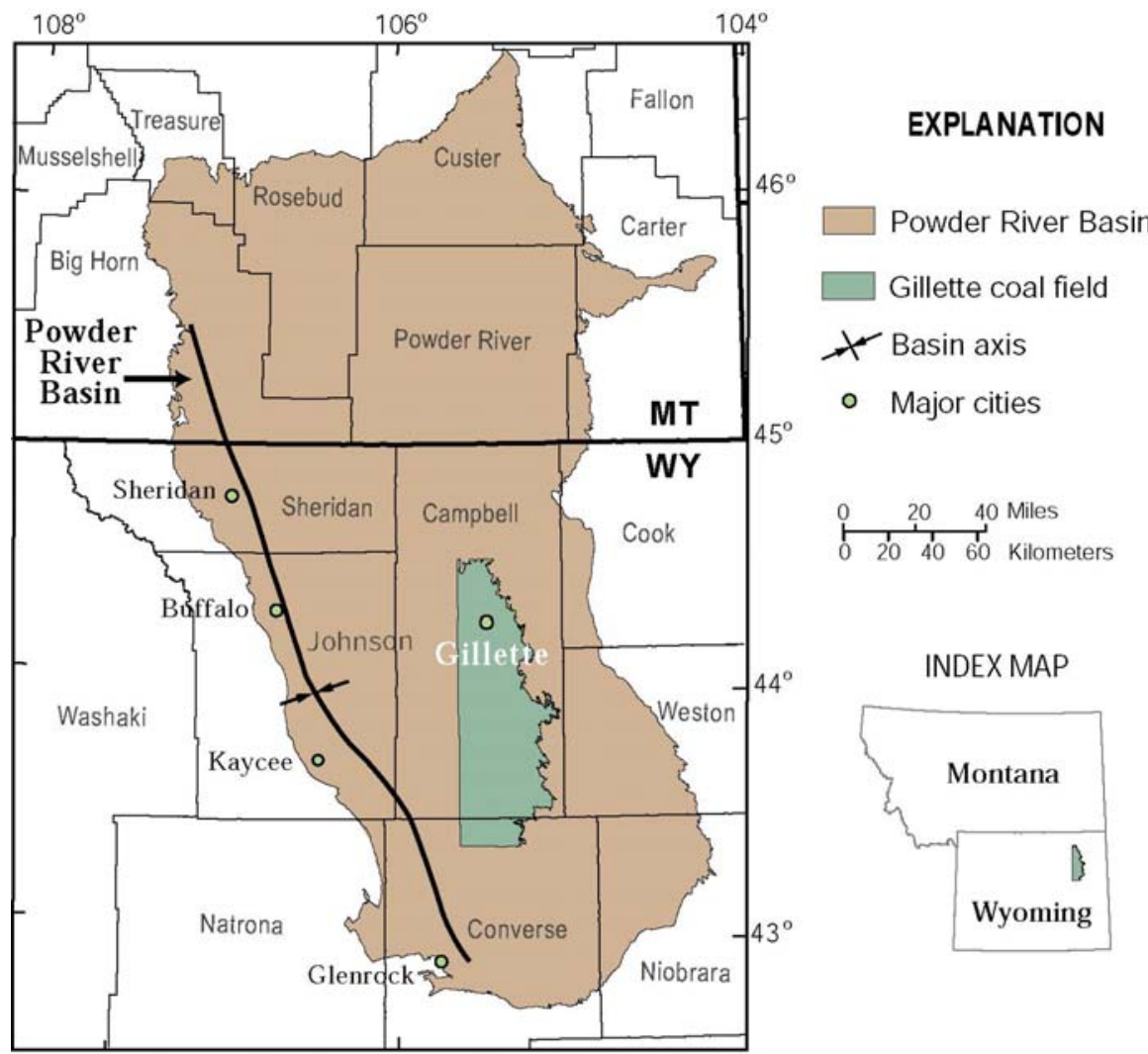

Figure 1. Map of the Powder River Basin, Wyoming and Montana showing the basin axis, counties, major cities, and the Gillette coal field. 
uneconomic for development.

Most coal currently being mined is used for electric power generation. Each coal-fired power plant is designed to work with coal beds that have specific ranges in calorific values [British thermal units (Btu)], concentrations of sulfur, and ash yield. Coal that does not fit the requirements of the power plant, because it has high sulfur content, must be cleaned or blended with other coal to meet power plant specifications for utilization. Additionally, the U.S. Clean Air Act Amendment (U.S. Environmental Protection Agency, 1996) has set new Federal regulations on sulfur dioxide emissions. Current standards limit flue-gas emissions from coalfired power plants to no more than 1.24 pounds of sulfur dioxide per million Btu (lb $\mathrm{SO}_{2} / \mathrm{mmBtu}$ ). The $\mathrm{lb} \mathrm{SO}_{2} / \mathrm{mmBtu}$ is a calculated value using the sulfur content of the coal (in percent) and the calorific value (in Btu) of the coal. The quality of coal, especially the sulfur content, is therefore a very important factor in determining what coal is economic for development.

The gross calorific value of Tertiary coal in the Powder River Basin, and specifically of the coal beds studied by the U.S. Geological Survey (USGS) in the Gillette coal field, is relatively low compared with the gross calorific value of coal from most other parts of the United States.

Although the Gillette coal has relatively low calorific value, it has much lower sulfur content and lower ash yield than coal from most other parts of the country. Many power plants can use coal with lower gross calorific values; therefore the Gillette coal is in high demand because it does not require cleaning and it can be utilized either exclusively or be blended with other coal to meet utilization specifications. Mines located within the Gillette study area (fig. 2) produced about 305 million short tons of coal, or about one third of the total national production, in 1999 (Resource

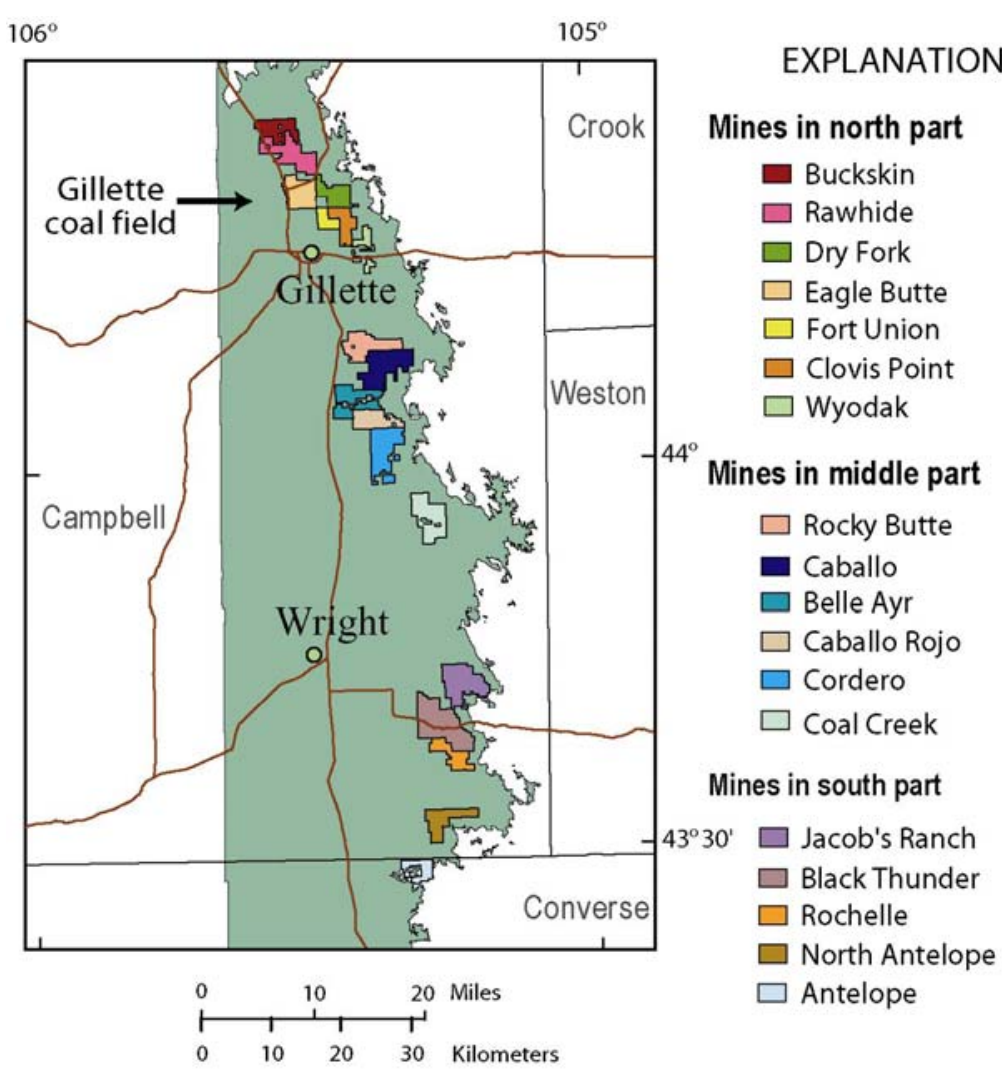

Figure 2. Location of coal mines in the Gillette coal field (modified from Ellis and others, 1999).
Data International, Inc., 2000).

The comparison of coal quality, which follows a general discussion of geology in the Powder River Basin (fig. 1), is organized with the discussion progressing from a regional overview to a detailed picture of the economically extractable coal beds recently studied in the Gillette coal field. Coal quality data is compiled from a variety of sources and consists of data on Wyoming coal, WyodakAnderson coal in the Powder River Basin, WyodakAnderson coal in the Gillette coal field, produced coal from mines in the Gillette coal field (fig. 2), and the five coal beds from the USGS study in the Gillette coal field. 


\section{AREA AND GEOLOGY OF THE POWDER RIVER BASIN AND GILLETTE COAL FIELD}

Minable coal discussed in this study is within the Tongue River Member of the Fort Union Formation in the Powder River Basin of Wyoming and Montana (fig. 3). The Powder River Basin is an asymmetrical structural basin with an axis that trends northwest-southeast (fig. 1) on the western side of the basin. The basin was formed during Late Laramide time by uplift of surrounding areas (including the Bighorn uplift to the west; the Casper arch, Laramie Range, and Hartville uplift to the south; and the Black Hills uplift to the east) and subsequent subsidence within the basin area (Curry, 1971; Perry and Flores, 1994).

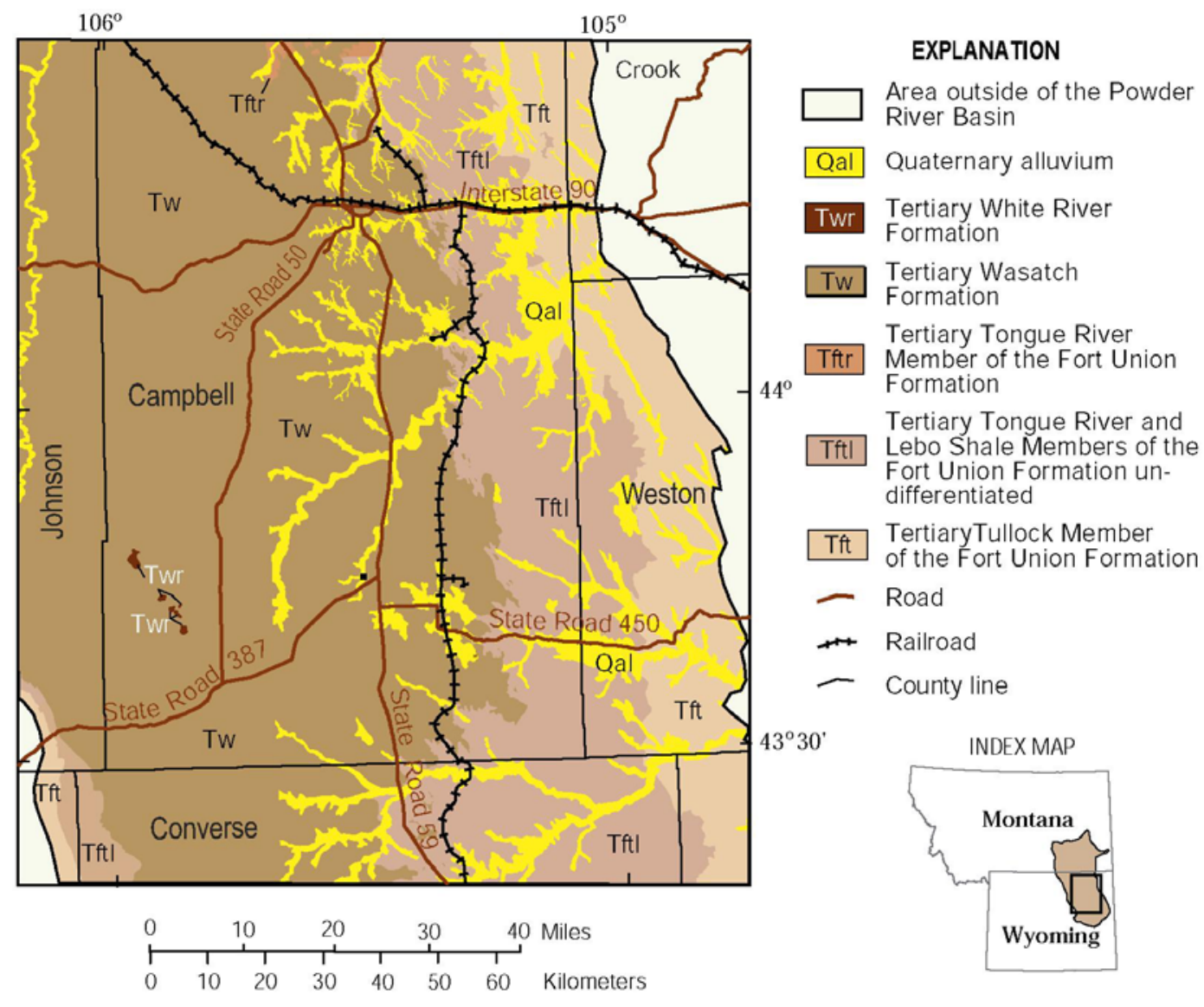

Figure 3. Map showing generalized geology in the part of the Powder River Basin around the Gillette coal field (modified from Ellis and others, 1999).

The basin, as defined by this study, is delineated by the contact between the Tertiary Fort Union Formation and the Late Cretaceous Hell Creek, Fox Hills, and Lance Formations, and Pierre Shale, on the northwest, west, south and east sides of the basin. In the north and northeast the basin boundary is defined by the course of the Yellowstone River. The Powder River Basin covers more than 22,000 sq mi (56,980 sq km) in Wyoming and Montana.

The Fort Union Formation is more than 5,200 $\mathrm{ft}(1,585 \mathrm{~m})$ thick in the deepest part of the basin. This formation is overlain by exposures of the Eocene Wasatch Formation, in the central part of 
the basin. Fort Union rocks dip an average of 20 to 25 degrees to the east along the western margin of the basin, and dip an average of 2 to 5 degrees to the west along the eastern margin of the basin. The formation consists of sandstone, shale, mudstone, and coal, and is divided into (from top to base) the Tongue River, Lebo Shale, and Tullock Members, based primarily on lithology, thickness, and color. The variations in Fort Union Formation rock types and characteristics are controlled by source material, environments of deposition, and influences on the sediment subsequent to deposition.

Fort Union coal in the Powder River Basin developed from peat accumulations in mires located adjacent to fluvial drainages. Most of the coal formed in thick, discontinuous, pod-like peat mires that were split continually by converging and diverging fluvial channels (Flores, 1986; Fort Union Coal Assessment Team, 1999). This resulted in a complex relationship of coal beds, indicated by the merging, splitting, and pinching-out of the beds over short distances.

The Gillette coal field is on the eastern edge of the Powder River Basin, Wyoming (fig. 1). The coal field boundary used for this study is very similar to the Gillette coal field area that was defined by USGS geologists in the past (Keefer and Schmidt, 1973; Denson and Keefer, 1974; Fort Union Coal Assessment Team, 1999) and was selected to include areas of active mines and adjacent areas where there is a potential for future coal development. The eastern boundary of the coal field is delineated by the outcrop of WyodakAnderson coal; mapped extent of Wyodak-Anderson clinker; or where that data is not present, the contact of the Wasatch Formation and the Fort Union Formation (Heffern and others, 1993; Heffern and Coates, 1997; Boyd and Ver Ploeg, 1997; Kent and others, 1980; and Coates and Heffern, 2000). The northern boundary is between T. $53 \mathrm{~N}$. and T. 52 $\mathrm{N}$. This boundary is about $5 \mathrm{mi}(8 \mathrm{~km})$ north of the Buckskin Mine (fig. 2). The southern boundary is between T. $40 \mathrm{~N}$. and T. $39 \mathrm{~N}$. The southernmost mine included in the coal field is the Antelope Mine (fig. 2). The western edge of the coal field is between R. $74 \mathrm{~W}$. and R. 73

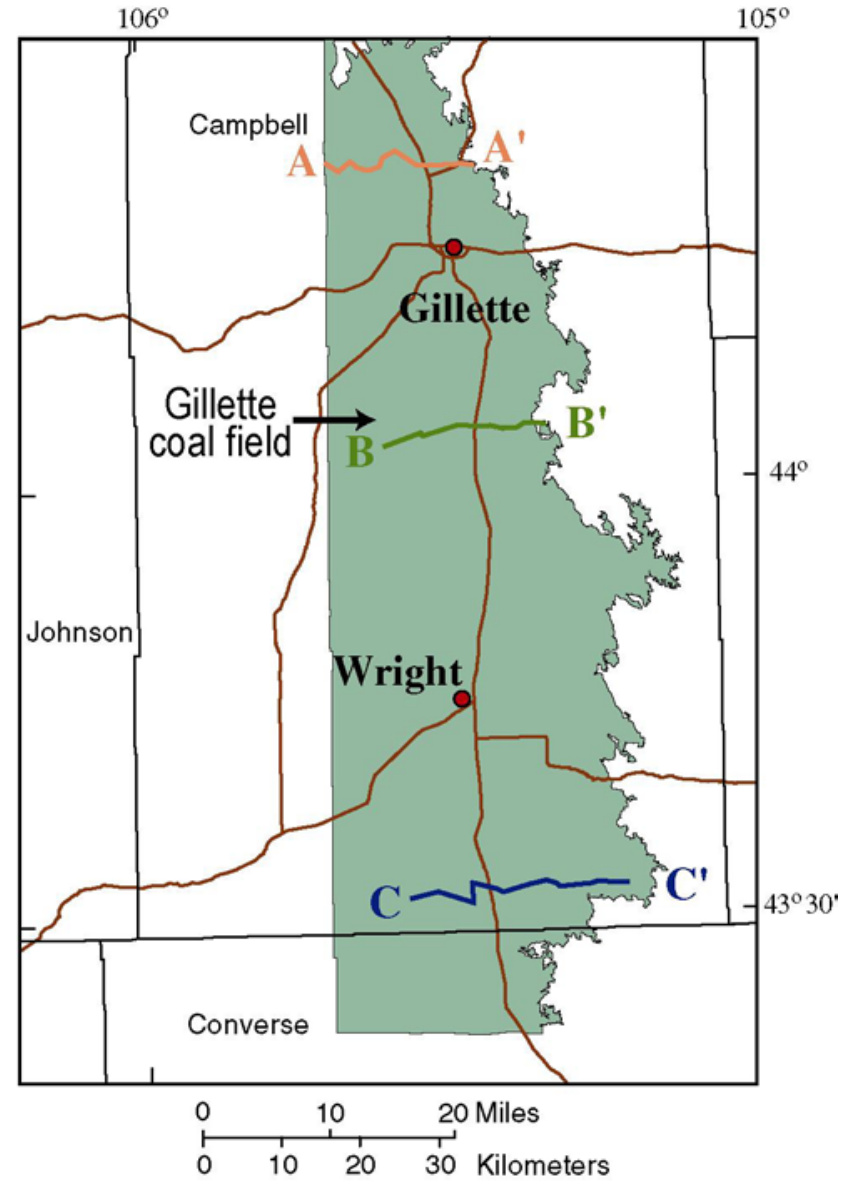

Figure 4. Map showing the location of stratigraphic cross sections through the north, middle and south parts of the Gillette coal field. $\mathrm{W}$. The western boundary is about $10 \mathrm{mi}(16 \mathrm{~km})$ from the westernmost mine in the Gillette coal field. The coal field encompasses about $1,500 \mathrm{sq} \mathrm{mi}(3,885 \mathrm{sq} \mathrm{km})$.

The Gillette coal field can be divided into northern, middle, and southern parts. West-to-east trending cross-sections, the locations of which are shown in figure 4, show examples of the lateral variations of Tertiary coal in the Gillette coal field (figs. 5, 6, and 7). On all three cross sections the coal beds split to the west and merge into one or more thick beds to the east. In the northern 
part of the coal field the correlation of coal beds is particularly difficult because there are many splits in the coal and beds are discontinuous where peat in the original coal swamp was eroded by contemporaneous fluvial channels. Coal beds in the middle and southern parts of the coal field are much more laterally continuous.

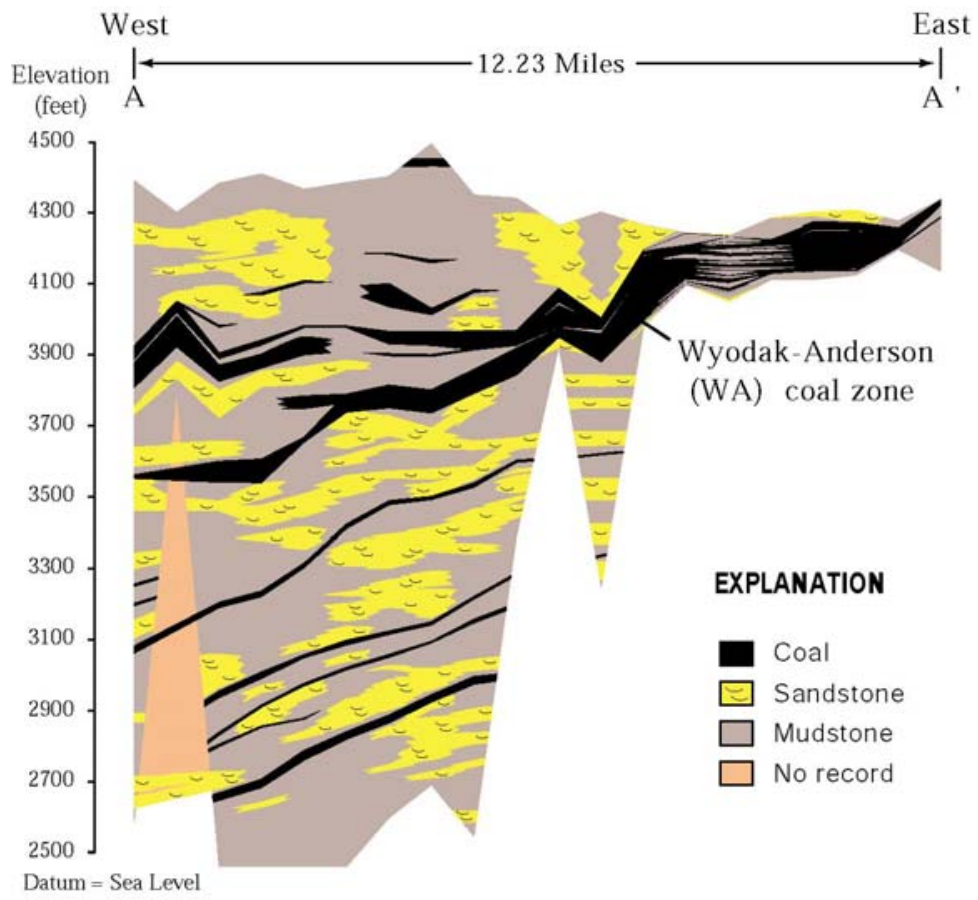

Figure 5. West to east structural cross section through the northern part of the Gillette coal field (modified from Flores and others, 1999). See figure 4 for location.

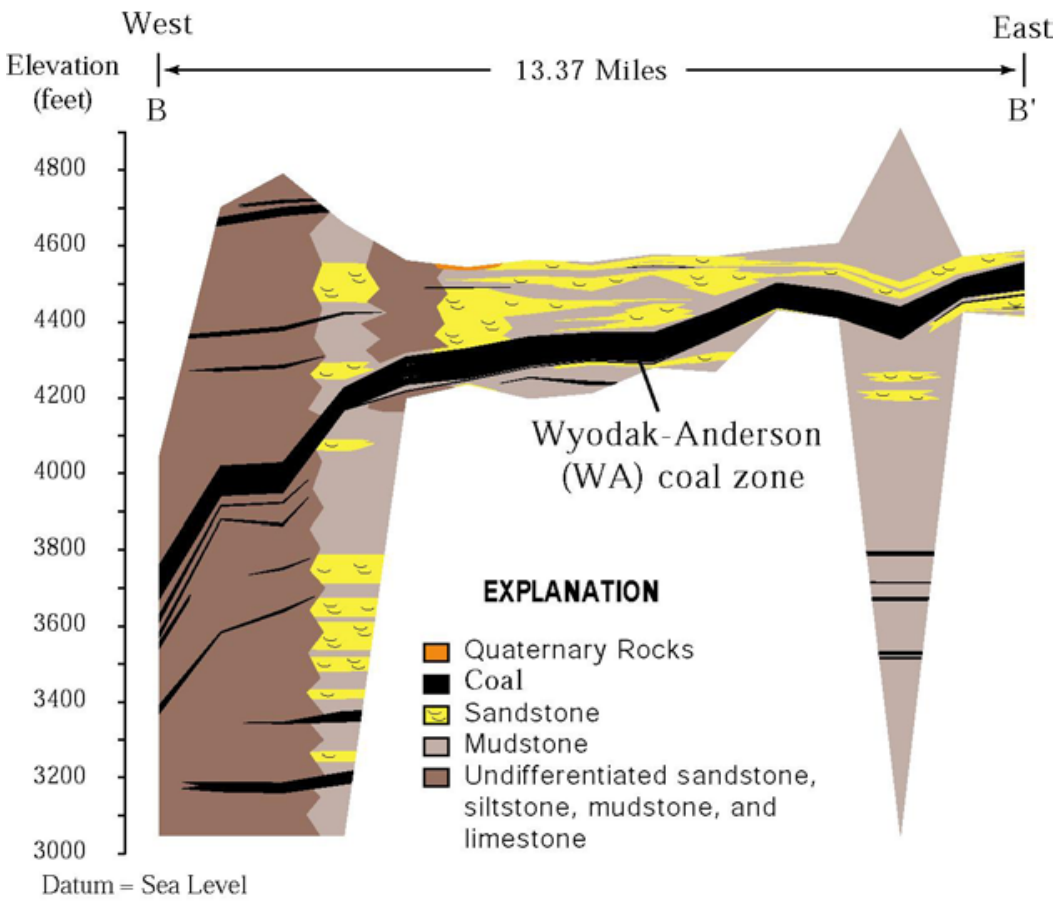

Figure 6 . West to east cross section through the middle part of the Gillette coal field (modified from Flores and others, 1999). See figure 4 for location. 


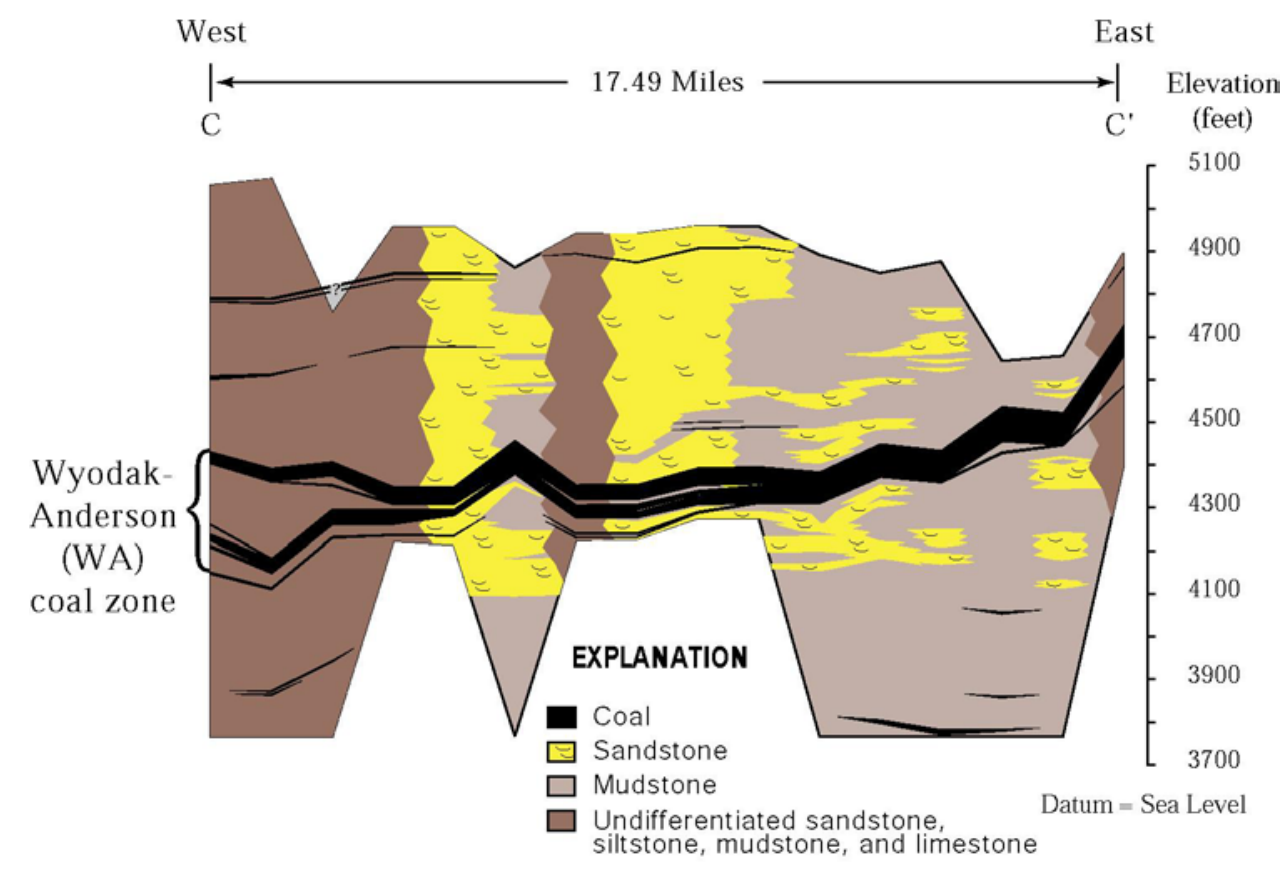

Figure 7. West to east structural cross section through the southern part of the Gillette coal field (modified from Flores and others, 1999). See figure 4 for location.

\section{WYOMING COAL CHARACTERISTICS AND COAL QUALITY}

Coal in Wyoming typically ranges in apparent rank from subbituminous to high-volatile A bituminous. The subbituminous coal is Tertiary or Cretaceous in age and occurs in almost all of the coal basins. Almost all bituminous coal is Cretaceous in age, although some deeply buried late Paleocene coal is also bituminous. Generally, older coal beds are higher in apparent rank, but high coal rank is more a factor of depth of burial (greater degree of metamorphism of the peat due to higher geothermal gradient and overlying pressure) than of age. The apparent rank of coal is classified based on its calorific value on a moist, mineral-matter free Btu (mmmfBtu) basis, percent of fixed carbon and volatile matter on a dry, mineral-matter-free basis, and its agglomerating characteristics (Wood and others, 1983, table 1). According to Wood and others (1983) subbituminous coal ranges from 8,300 to $11,500 \mathrm{mmmfBtu}$ and is non-agglomerating, and bituminous coal ranges from 10,500 to $14,000 \mathrm{mmmfBtu}$ and is commonly agglomerating. The gross calorific values $(\mathrm{Btu})$ of coal produced from various coal fields in Wyoming are shown in Table 1. According to Glass (2000) coal being mined in the Powder River Basin ranges from about 7,420 to $10,410 \mathrm{Btu}$ and is subbituminous in apparent rank.

Higher rank bituminous coal in Wyoming generally has moisture content less than 15 percent, volatile matter content between 30 and 40 percent, and fixed carbon content greater than 40 percent. The lower rank subbituminous coal has moisture content between 20 and 30 percent and volatile matter and fixed carbon content of about 30 percent (Glass, 2000).

Ash yield and sulfur content in coal is related to the depositional environment in which the peat accumulated and the volume and type of sediment deposited in the peat. According to Wood and 
others (1983), sulfur content and ash yield can be divided into high, medium, and low categories. The values for these categories are shown in table 2. Ash yield and sulfur content of the Paleocene coal mined from the Powder River Basin tends to be low, but ash yield and sulfur content for coal of all ages and throughout the state of Wyoming varies greatly. Sulfur content, ash yield, and trace element content in Cretaceous coal is generally higher than that found in Tertiary coal. These higher values in Cretaceous coal are probably caused by the influx of marine sediment into Cretaceous peat swamps (Flores and others, 1994). In low sulfur coal the form of sulfur is primarily organic, whereas is the high sulfur coal it is mainly pyritic. Much of the pyritic sulfur can be removed from coal mechanically through cleaning processes.

Table 1. Summary of the apparent rank and calorific value of mined coal from coal fields in Wyoming. Btu is British thermal units. Modified from Glass (2000)

\begin{tabular}{|l|l|c|c|}
\hline \multicolumn{1}{|c|}{ Coal field } & \multicolumn{1}{|c|}{ Apparent coal rank } & $\begin{array}{c}\text { Range of gross } \\
\text { calorific value } \\
\text { (Btu/lb) }\end{array}$ & $\begin{array}{c}\text { Mean of gross } \\
\text { calorific value } \\
\text { (Btu/lb) }\end{array}$ \\
\hline Powder River-NW & Subbituminous & $9,000-10,410$ & 9,410 \\
\hline Powder River-East & Subbituminous & $7,420-9,600$ & 8,580 \\
\hline Powder River- South & Subbituminous & $7,610-8,870$ & 7,710 \\
\hline Hanna & Subbituminous and bituminous & $8,310-12,600$ & 11,030 \\
\hline Green River & Subbituminous & $9,290-10,000$ & 9,480 \\
\hline Hams Fork & Subbituminous & $9,270-10,000$ & 9,570 \\
\hline Bighorn & Bituminous & $10,730-11,246$ & 10,970 \\
\hline
\end{tabular}

Table 2. Designation of low, medium, and high categories for total sulfur content and ash yield in coal, as defined in Wood and others, 1983

\begin{tabular}{|l|c|c|c|}
\hline $\begin{array}{l}\text { Coal quality } \\
\text { parameter }\end{array}$ & Low & Medium & High \\
\hline Total sulfur (percent) & Less than 1 & 1 to 3 & Greater than 3 \\
\hline Ash yield (percent) & Less than 8 & 8 to 15 & Greater than 15 \\
\hline
\end{tabular}

\section{WYODAK-ANDERSON COAL CHARACTERISTICS AND COAL QUALITY IN THE POWDER RIVER BASIN, WYOMING AND MONTANA}

Coal included in this study in the Gillette coal field, Wyoming is primarily within the WyodakAnderson coal zone that was defined by the Fort Union Assessment Team (1999) in their study of coal in the Powder River Basin of Wyoming and Montana. According to their data, the WyodakAnderson coal zone in the Powder River Basin has a maximum net coal thickness, defined as the summed thickness of all coal beds greater than $2.5 \mathrm{ft}(0.76 \mathrm{~m})$ thick, of $284 \mathrm{ft}(86.6 \mathrm{~m})$. The entire zone is more than $600 \mathrm{ft}(183 \mathrm{~m})$ thick, measured from the top of the uppermost coal to the base of the lowermost coal, in the central part of the basin. The zone contains up to six coal beds 
in a given location. Coal beds average $25 \mathrm{ft}(7.6 \mathrm{~m})$ in thickness, and are separated by clastic sedimentary rocks ranging from a few feet to $150 \mathrm{ft}(45.7 \mathrm{~m})$ in thickness.

Wyodak-Anderson coal is generally considered to be clean, and compliant with $\mathrm{SO}_{2}$ emissions standards (U.S. Environmental Protection Agency, 1996. Arithmetic mean values of the Wyodak-Anderson coal from samples collected from 300 locations throughout the Powder River Basin indicate that the coal contains low percentages of total sulfur and has a low ash yield (table $3)$.

Table 3. Coal quality summary data for Wyodak-Anderson coal in the Powder River Basin, Wyoming and Montana. The table was modified from Stricker and Ellis (1999). Proximate and ultimate analyses are reported on an as-received basis. Trace elements are reported in parts per million and are reported on a whole-coal and remnant-moisture basis. $L$ indicates that the value was below the detection limit for the measuring device

\begin{tabular}{|l|c|c|c|c|}
\hline \multirow{2}{*}{$\begin{array}{c}\text { Coal quality } \\
\text { parameter }\end{array}$} & \multirow{2}{*}{$\begin{array}{c}\text { Number of } \\
\text { samples }\end{array}$} & \multicolumn{2}{c|}{ Range } & \multirow{2}{*}{ Mean } \\
\cline { 3 - 4 } & 300 & 14.50 & 42.30 & 27.66 \\
\hline Moisture (percent) & 279 & 2.86 & 25.06 & 6.44 \\
\hline Ash (percent) & 279 & 0.06 & 2.40 & 0.48 \\
\hline Total sulfur (percent) & 277 & 3,740 & 9,950 & 8,220 \\
\hline Gross calorific value (Btu) & 277 & 0.14 & 7.88 & 1.24 \\
\hline LbSO/million Btu & 277 & 4,580 & 10,560 & 8,820 \\
\hline Moist, mineral-matter free Btu & 144 & $0.01 \mathrm{~L}$ & 17 & 0.49 \\
\hline Antimony & 158 & $0.20 \mathrm{~L}$ & 19 & 2.6 \\
\hline Arsenic & 151 & $0.078 \mathrm{~L}$ & 3.3 & 0.54 \\
\hline Beryllium & 151 & $0.007 \mathrm{~L}$ & 3.0 & 0.21 \\
\hline Cadmium & 161 & $0.59 \mathrm{~L}$ & 50 & 6.1 \\
\hline Chromium & 160 & $0.38 \mathrm{~L}$ & 27 & 1.9 \\
\hline Cobalt & 162 & $0.50 \mathrm{~L}$ & 17 & 3.0 \\
\hline Lead & 161 & 0.18 & 210 & 26 \\
\hline Manganese & 162 & $0.006 \mathrm{~L}$ & 27 & 0.13 \\
\hline Mercury & 161 & $0.71 \mathrm{~L}$ & 35 & 4.6 \\
\hline Nickel & 151 & $0.08 \mathrm{~L}$ & 16 & 1.1 \\
\hline Selenium & 157 & $0.11 \mathrm{~L}$ & 12 & 1.3 \\
\hline Uranium & & & & \\
\hline
\end{tabular}

Original analytical data from which these values were calculated consists of proximate and ultimate analyses and trace element analyses from the U.S. Geological Survey COALQUAL database (Bragg and others, 1994). Table 3 reports a range in Wyodak-Anderson total sulfur content of 0.06 to 2.4 percent with a mean of 0.48 percent, and a range in ash yield of from 2.86 to 25.06 percent with a mean of 6.44 percent. Pounds of $\mathrm{SO}_{2}$ per million Btu for Wyodak-

Anderson coal ranged from 0.14 to 7.88 with a mean of 1.24 and the gross calorific value of the coal ranged from 3,740 to $9,950 \mathrm{Btu} / \mathrm{lb}$, with a mean of $8,220 \mathrm{Btu} / \mathrm{lb}$ 


\section{CHARACTERISTICS AND QUALITY OF WYODAK-ANDERSON AND OTHER COAL IN THE GILLETTE COAL FIELD, WYOMING}

The Wyodak-Anderson coal zone in the Gillette coal field includes (from upper to lower) the Smith, Swartz, Anderson, Wyodak, Canyon, and Werner coal beds (Ellis and others, 1999). These beds are in the late Paleocene Tongue River Member of the Fort Union Formation (fig. 3). WyodakAnderson coal quality in the Gillette coal field study area (tables 4,5 , and 6) is very similar to that shown for the WyodakAnderson coal throughout the Powder River Basin (table 3).

Table 4. Coal quality summary data using weighted averages, one value for each parameter at each data point location, for Wyodak-Anderson coal in the Gillette coal field. The table was modified from Ellis and others (1999). Proximate and ultimate analyses are reported on an asreceived basis. Trace elements are reported in parts per million. L indicates that the value was below the detection limit for the measuring device

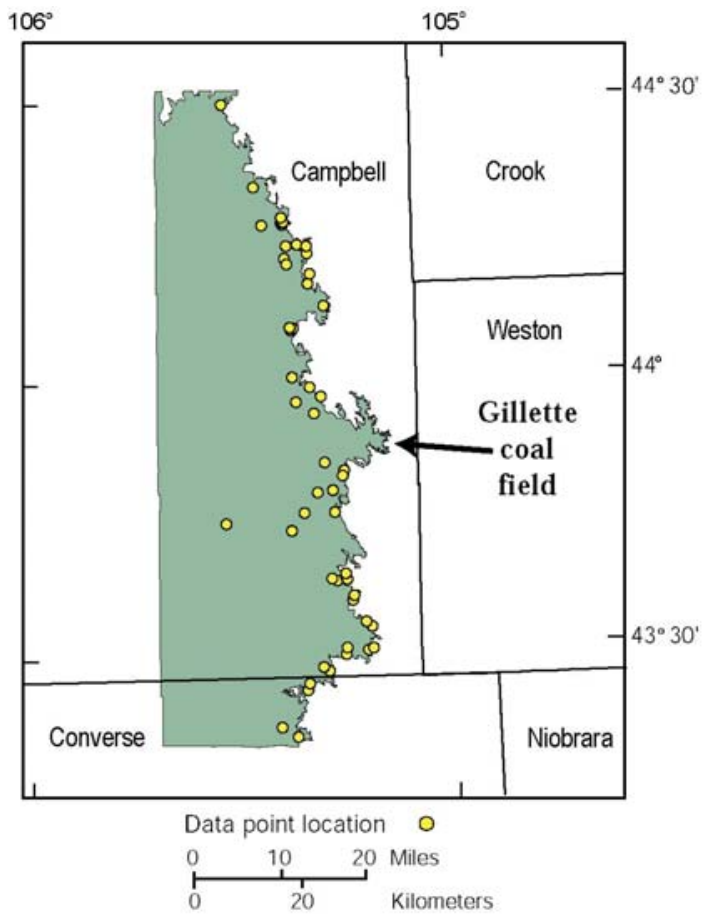

Figure 8. Map showing locations in the Gillette coal field where samples from the Wyodak-Anderson coal zone were collected for coal quality alyses (modified from Ellis and others, 1999).

\begin{tabular}{|l|c|c|c|c|}
\hline \multirow{2}{*}{$\begin{array}{c}\text { Coal Quality } \\
\text { Parameter }\end{array}$} & \multirow{2}{*}{$\begin{array}{c}\text { Number of } \\
\text { samples }\end{array}$} & \multicolumn{2}{c|}{ Range } & \multirow{2}{*}{ Mean } \\
\cline { 3 - 4 } & 108 & 14.5 & 42.30 & 27.47 \\
\hline Moisture (percent) & 87 & 3.5 & 25.06 & 7.45 \\
\hline Ash (percent) & 87 & 0.20 & 1.16 & 0.48 \\
\hline Total sulfur (percent) & 85 & 3,740 & 9,950 & 8,220 \\
\hline Gross calorific value (Btu) & 85 & 0.44 & 3.27 & 1.25 \\
\hline LbSO/million Btu & 85 & 4,580 & 10,560 & 8,910 \\
\hline Moist, mineral-matter free Btu & 49 & $0.01 \mathrm{~L}$ & 17 & 0.72 \\
\hline Antimony & 62 & $0.20 \mathrm{~L}$ & 19 & 2.3 \\
\hline Arsenic & 64 & $0.078 \mathrm{~L}$ & 3.3 & 0.35 \\
\hline Beryllium & 56 & $0.007 \mathrm{~L}$ & 3.0 & 0.39 \\
\hline Cadmium & 65 & $0.59 \mathrm{~L}$ & 50 & 7.0 \\
\hline Chromium & 65 & $0.38 \mathrm{~L}$ & 27 & 2.3 \\
\hline Cobalt & 66 & $0.50 \mathrm{~L}$ & 17 & 2.9 \\
\hline Lead & 66 & 0.18 & 210 & 22 \\
\hline Manganese & 66 & $0.006 \mathrm{~L}$ & 27 & 0.17 \\
\hline Mercury & 66 & $0.71 \mathrm{~L}$ & 35 & 5.0 \\
\hline Nickel & 56 & $0.08 \mathrm{~L}$ & 16 & 1.4 \\
\hline Selenium & 61 & $0.11 \mathrm{~L}$ & 12 & 1.5 \\
\hline Uranium & & & & \\
\hline
\end{tabular}


In the Gillette coal field there were a total of 108 locations from which samples were collected. Non-confidential data point locations in the coal field are shown in figure 8. Table 4 shows summary data for Wyodak-Anderson coal in the Gillette coal field. The values shown in this table are weighted averages of Wyodak-Anderson coal quality data at each of the 108 data point locations, one value for each coal quality parameter at each data point location. The table shows total sulfur content that ranged from 0.20 to 1.16 percent with a mean of 0.48 percent and ash yield that ranged from 3.5 to 25.06 percent with a mean of 7.45 percent. Pounds of $\mathrm{SO}_{2}$ per million Btu for Wyodak-Anderson coal in the coal field ranged from 0.44 to 3.27 with a mean of 1.25 and the gross calorific value of the coal samples ranged from 3,740 to $9,950 \mathrm{Btu} / \mathrm{lb}$ with a mean of 8,220 Btu/lb (Ellis and others, 1999).

Table 5. Proximate, ultimate and calorific values using all sample analyses, more than one sample at each data point location, from coal beds in the Wyodak-Anderson coal zone in the Gillette coal field. Calculated from data in Flores and others (1999) and from confidential sources. All values are reported on an asreceived basis. MmmfBtu is moist, mineral-matter free Btu

\begin{tabular}{|l|c|c|c|c|}
\hline \multicolumn{1}{|c|}{ Chemical parameter } & $\begin{array}{c}\text { Number of } \\
\text { samples }\end{array}$ & $\begin{array}{c}\text { Minimum } \\
\text { value }\end{array}$ & Maximum value & Mean value \\
\hline Moisture (percent) & 226 & 14.5 & 42.3 & 29.16 \\
\hline Ash (percent) & 226 & 2.5 & 32 & 7.05 \\
\hline Total sulfur (percent) & 227 & 0.1 & 4.6 & 0.54 \\
\hline Gross calorific value (Btu) & 161 & 4,690 & 9,950 & 7,870 \\
\hline LbSO $_{2} /$ million Btu & 161 & 0.2 & 6.43 & 1.62 \\
\hline MmmfBtu & 161 & 6,940 & 10,570 & 8,580 \\
\hline Organic sulfur (percent) & 215 & 0.06 & 1.55 & 0.37 \\
\hline Pyritic sulfur (percent) & 199 & 0.01 & 3.09 & 0.16 \\
\hline Sulfate sulfur (percent) & 187 & 0.01 & 0.47 & 0.03 \\
\hline Fixed carbon (percent) & 226 & 4.1 & 44.5 & 33.41 \\
\hline Volatile matter (percent) & 226 & 21.4 & 55.7 & 30.38 \\
\hline
\end{tabular}

Table 6. Trace element content of coal samples from beds in the Wyodak-Anderson coal zone in the Gillette coal field. Calculated from data in Flores and others (1999). All values are reported in parts per million and are on a whole-coal and remnant-moisture basis

\begin{tabular}{|l|c|c|c|c|}
\hline $\begin{array}{c}\text { Chemical } \\
\text { parameter }\end{array}$ & $\begin{array}{c}\text { Number of } \\
\text { samples }\end{array}$ & Minimum value & Maximum value & Mean value \\
\hline Antimony & 281 & 0.01 & 17 & 0.34 \\
\hline Arsenic & 282 & 0.23 & 150 & 3.3 \\
\hline Beryllium & 215 & 0.02 & 9.1 & 0.80 \\
\hline Cadmium & 273 & 0.007 & 3.0 & 0.09 \\
\hline Chromium & 285 & 0.59 & 66 & 7.2 \\
\hline Cobalt & 284 & 0.27 & 27 & 2.1 \\
\hline Lead & 286 & 0.14 & 20 & 2.9 \\
\hline Manganese & 286 & 0.18 & 220 & 27 \\
\hline Mercury & 229 & 0.006 & 27 & 0.11 \\
\hline Nickel & 286 & 0.53 & 67 & 5.4 \\
\hline Selenium & 273 & 0.05 & 16 & 1.0 \\
\hline Uranium & 282 & 0.01 & 12 & 0.98 \\
\hline
\end{tabular}


A more detailed coal quality summary for each of the coal beds sampled from the WyodakAnderson coal zone in the Gillette coal field is shown in Tables 5 and 6 . These two tables show proximate and ultimate analyses, gross calorific value, and selected trace element content of coal from over 200 sample analyses, more than one sample collected from most data point locations. The values reported for individual samples, shown in Tables 5 and 6, have a much larger range than are reported for the weighted averages, shown in Table 4. This difference in values indicates that the quality of coal produced can be customized through selective mining of coal beds, and blending of coal to meet individual coal quality standards.

About 305 million short tons of coal were supplied to coal-fired powered power plants in 1999 from coal mines in the Gillette coal field (fig. 2). According to the 2000 COALdat database (Resource Data International, Inc., 2000), coal supplied to electrical power plants in 1999 from these mines had mean values of 0.31 percent total sulfur, 5.21 percent ash yield, 0.72 pounds of $\mathrm{SO}_{2}$ per million Btu, and gross calorific value of $8,630 \mathrm{Btu} / \mathrm{lb}$. Table 7 shows the quality of coal produced from these mines, reported by location of the mines in the northern, middle, and southern parts of the coal field (fig. 2).

Table 7. Summary of coal quality and production of coal from mines in the Gillette coal field supplied to coal-fired power plants in 1999 (Resource Data International, Inc., 2000). Coal quality parameters are listed by the location of the mines within the coal field (fig. 2). The "combined" category is coal that was supplied to power plants from mines located in different parts of the coal field. Proximate, ultimate, and heat of combustion values are reported on an as-received basis. Btu is British thermal units. Production is reported in millions of short tons (mst) and rounded to one decimal place

\begin{tabular}{|l|c|c|c|c|c|}
\hline $\begin{array}{l}\text { Coal quality parameter and } \\
\text { 1999 production }\end{array}$ & Northern part & Middle part & Southern part & $\begin{array}{c}\text { Combined } \\
\text { areas }\end{array}$ & $\begin{array}{c}\text { All mines in } \\
\text { Gillette coal } \\
\text { field }\end{array}$ \\
\hline Minimum ash (percent) & 4.37 & 3.7 & 3.8 & 4.22 & 3.7 \\
\hline Maximum ash (percent) & 9.3 & 45.03 & 18.9 & 5.5 & 45.03 \\
\hline Mean ash (percent) & 5.66 & 5.39 & 5.11 & 4.68 & 5.21 \\
\hline $\begin{array}{l}\text { Minimum total sulfur } \\
\text { (percent) }\end{array}$ & 0.23 & 0.21 & 0.15 & 0.25 & 0.15 \\
\hline $\begin{array}{l}\text { Maximum total sulfur } \\
\text { (percent) }\end{array}$ & 1.05 & 0.7 & 5.32 & 0.4 & 5.32 \\
\hline Mean total sulfur (percent) & 0.45 & 0.33 & 0.29 & 0.32 & 0.31 \\
\hline $\begin{array}{l}\text { Minimum gross calorific } \\
\text { value (Btu) }\end{array}$ & 7,940 & 8,190 & 8,100 & 8,300 & 7,940 \\
\hline $\begin{array}{l}\text { Maximum gross calorific } \\
\text { value (Btu) }\end{array}$ & 8,790 & 8,770 & 9,410 & 8,850 & 9,410 \\
\hline $\begin{array}{l}\text { Mean gross calorific value } \\
\text { (Btu) }\end{array}$ & 8,300 & 8,430 & 8,770 & 8,490 & 8,630 \\
\hline Minimum IbSO $/$ /million Btu & 0.55 & 0.49 & 0.34 & 0.58 & 0.34 \\
\hline Maximum IbSO$/$ million Btu & 2.53 & 1.71 & 12.13 & 0.95 & 12.13 \\
\hline Mean IbSO$/$ million Btu & 1.09 & 0.78 & 0.66 & 0.76 & 0.72 \\
\hline Production (mst) & 26.8 & 94.8 & 167.0 & 16.8 & 305.3 \\
\hline
\end{tabular}




\section{QUALITY OF ECONOMICALLY EXTRACTABLE COAL BEDS ASSESSED IN THE GILLETTE COAL FIELD STUDY}

The recent USGS study of economically extractable coal in the Gillette coal field concentrated on five coal units. These units are currently designated, from upper to lower, as the Wyodak rider, Upper Wyodak, Canyon, Lower Wyodak/Werner, and Gates/Kennedy. The Wyodak rider is equivalent to the Smith bed of Kent and others (1980) and the Roland/Badger of Pierce and others (1990). The Upper Wyodak is the same as the Upper Wyodak of Kent and others (1980). The Canyon is equivalent to the Canyon of Kent and others (1980), which is an upper split of the lower Wyodak/Werner. The lower Wyodak/Werner is equivalent to the lower Wyodak of Kent and others (1980), which includes the Werner of Pierce and others (1990). The Gates/Kennedy coal is equivalent to the Gates of Kent and others (1980) and the upper Kennedy of Pierce and others (1990). Glass (2000) contains a fence diagram, modified from several U.S. Geological Survey publications, in which many of the coal bed correlations and bed names used in various parts of the Powder River Basin are clarified. This fence diagram shows the Anderson bed as equivalent to what is called the Upper Wyodak, the Gates coal as being equivalent to the Wall, and the Kennedy coal as equivalent to the Pawnee.

To summarize, the coal units included in the Gillette study area are stratigraphically equivalent to (from uppermost to lowermost) the Roland, Smith, Badger, Wyodak, Anderson, Canyon, Werner, Gates or Wall, and Kennedy or Pawnee coal beds as defined in previous publications. All of these coal beds are subbituminous $\mathrm{C}$ in apparent rank. According to data from the recent study and from statistics reported in Glass (2000), the coal beds included have a maximum thickness of about $200 \mathrm{ft}(61 \mathrm{~m})$, contain from 15 to 35 percent moisture and 0.13 to 2.3 percent total sulfur, have an ash yield of from 2.5 to 19.68 percent, have gross calorific values from 7,130 to 9,950 $\mathrm{Btu} / \mathrm{lb}$, and have calculated values for pounds of sulfur dioxide per million Btu's that range from 0.25 to 3.68 .

The data set used for this coal quality study of the economically recoverable coal beds in the Gillette coal field included analytical data from published sources (Bragg and others, 1994; Flores and others, 1999) and unpublished confidential data from various sources. The data set is made up of 140 samples for which proximate and ultimate analyses and heat of combustion were run on an as-received basis and 157 samples that were analyzed for content of potentially hazardous trace elements, measured in parts per million on a whole-coal and remnant-moisture basis. A summary of the coal quality data is shown in Tables 8 and 9. The data set does not include analyses for the Canyon or Gates/Kennedy coal, but Table 8 includes data for the Canyon bed from Glass (2000). 
Table 8. Proximate and ultimate analyses and calorific values of economically extractable coal in the Gillette coal field. Proximate and ultimate analyses are reported in percent by weight. All analyses are reported on an on an as-received basis. No data was available for the Gates/Kennedy coal bed

\begin{tabular}{|c|c|c|c|c|c|c|}
\hline Parameter & Data & $\begin{array}{l}\text { Wyodak } \\
\text { rider }\end{array}$ & $\begin{array}{l}\text { Upper } \\
\text { Wyodak }\end{array}$ & $\begin{array}{c}\text { Lower Wyodak/ } \\
\text { Werner }\end{array}$ & $\begin{array}{c}\text { Wyodak rider, Upper } \\
\text { Wyodak, and Lower } \\
\text { Wyodak/Werner } \\
\text { combined }\end{array}$ & $\begin{array}{l}\text { Canyon } \\
\text { (Glass, } \\
2000)\end{array}$ \\
\hline \multirow[t]{4}{*}{ Moisture } & Number of samples & 4 & 127 & 9 & 140 & 9 \\
\hline & Minimum (percent) & 20 & 15 & 25 & 15 & 26.5 \\
\hline & Maximum (percent) & 27 & 35 & 32 & 35 & 31.5 \\
\hline & Mean (percent) & 23 & 27 & 27 & 27 & 29.6 \\
\hline \multirow[t]{4}{*}{ Ash } & Number of samples & 4 & 127 & 9 & 140 & 9 \\
\hline & Minimum (percent) & 9.7 & 2.5 & 4.2 & 2.5 & 3.1 \\
\hline & Maximum (percent) & 19.1 & 19.68 & 8.2 & 19.68 & 7.4 \\
\hline & Mean (percent) & 12.90 & 5.80 & 5.83 & 6.01 & 5.1 \\
\hline \multirow[t]{4}{*}{ Total sulfur } & Number of samples & 4 & 127 & 9 & 140 & 9 \\
\hline & Minimum (percent) & 0.80 & 0.13 & 0.20 & 0.13 & 0.14 \\
\hline & Maximum (percent) & 1.50 & 2.30 & 0.40 & 2.30 & 0.92 \\
\hline & Mean (percent) & 1.13 & 0.46 & 0.27 & 0.46 & 0.34 \\
\hline \multirow{4}{*}{$\begin{array}{l}\text { Organic } \\
\text { sulfur }\end{array}$} & Number of samples & 4 & 116 & 9 & 129 & \\
\hline & Minimum (percent) & 0.39 & 0.06 & 0.15 & 0.06 & \\
\hline & Maximum (percent) & 0.83 & 1.10 & 0.37 & 1.10 & \\
\hline & Mean (percent) & 0.60 & 0.32 & 0.23 & 0.32 & \\
\hline \multirow{4}{*}{$\begin{array}{l}\text { Pyritic } \\
\text { sulfur }\end{array}$} & Number of samples & 4 & 103 & 8 & 115 & \\
\hline & \begin{tabular}{|l|} 
Minimum (percent) \\
\end{tabular} & 0.07 & 0.01 & 0.01 & 0.01 & \\
\hline & Maximum (percent) & 1.09 & 1.63 & 0.04 & 1.63 & \\
\hline & Mean (percent) & 0.56 & 0.14 & 0.03 & 0.15 & \\
\hline \multirow{4}{*}{$\begin{array}{l}\text { Sulfate } \\
\text { sulfur }\end{array}$} & Number of samples & 1 & 96 & 8 & 105 & \\
\hline & Minimum (percent) & 0.01 & 0.01 & 0.01 & 0.01 & \\
\hline & Maximum (percent) & 0.01 & 0.47 & 0.03 & 0.47 & \\
\hline & Mean (percent) & 0.01 & 0.03 & 0.02 & 0.03 & \\
\hline \multirow{4}{*}{$\begin{array}{l}\mathrm{Lb} \mathrm{SO}_{2} \\
\text { /million } \\
\text { Btu }\end{array}$} & Number of samples & 4 & 62 & 9 & 75 & \\
\hline & Minimum & 0.35 & 0.25 & 1.45 & 0.25 & \\
\hline & Maximum & 0.71 & 3.68 & 3.02 & 3.68 & \\
\hline & Mean & 0.55 & 1.70 & 2.40 & 1.73 & \\
\hline \multirow{4}{*}{$\begin{array}{l}\text { Gross } \\
\text { calorific } \\
\text { value }\end{array}$} & Number of samples & 4 & 62 & 9 & 75 & 9 \\
\hline & Minimum (Btu) & 7,890 & 7,170 & 7,580 & 7,170 & 7,540 \\
\hline & Maximum (Btu) & 9,410 & 9,950 & 8,980 & 9,950 & 8,610 \\
\hline & Mean (Btu) & 8,500 & 8,570 & 8,470 & 8,550 & 8,290 \\
\hline \multirow{4}{*}{\begin{tabular}{|l|} 
Moist, \\
mineral- \\
matter free \\
Btu \\
\end{tabular}} & Number of samples & 4 & 62 & 9 & 75 & \\
\hline & Minimum & 9,160 & 8,250 & 8,310 & 8,250 & \\
\hline & Maximum & 10,560 & 10,570 & 9,410 & 10,570 & \\
\hline & Mean & 9,880 & 9,190 & 9,040 & 9,210 & \\
\hline \multirow{4}{*}{\begin{tabular}{|l} 
Fixed \\
carbon
\end{tabular}} & Number of samples & 4 & 127 & 140 & 9 & 9 \\
\hline & Minimum (percent) & 29.7 & 25.5 & 4.1 & 31.8 & 4.1 \\
\hline & Maximum (percent) & 33.1 & 44.5 & 44.5 & 38.4 & 39.3 \\
\hline & Mean (percent) & 30.8 & 35.0 & 34.8 & 34.6 & 33.6 \\
\hline \multirow{4}{*}{$\begin{array}{l}\text { Volatile } \\
\text { matter }\end{array}$} & Number of samples & 4 & 127 & 9 & 140 & 9 \\
\hline & Minimum (percent) & 30.30 & 24.75 & 28.80 & 24.75 & 28.7 \\
\hline & Maximum (percent) & 37.80 & 37.80 & 55.70 & 55.70 & 33.3 \\
\hline & Mean (percent) & 33.23 & 31.71 & 33.50 & 31.87 & 30.7 \\
\hline
\end{tabular}


Table 9. Values for potentially hazardous air pollutant trace elements in economically extractable coal in the Gillette coal field. Reported in parts per million on a whole-coal and remnant-moisture basis. No data was available for the Canyon or Gates/Kennedy coal beds

\begin{tabular}{|c|c|c|c|c|c|}
\hline Parameter & Data & Wyodak rider & Upper Wyodak & Lower Wyodak/ Werner & All three coal beds \\
\hline \multirow{4}{*}{ Antimony } & Number of samples & 4 & 138 & 10 & 152 \\
\hline & Minimum & 0.52 & 0.01 & 0.09 & 0.01 \\
\hline & Maximum & 1.2 & 2.7 & 1.04 & 2.7 \\
\hline & Mean & 0.76 & 0.21 & 0.38 & 0.24 \\
\hline \multirow[t]{4}{*}{ Arsenic } & Number of samples & 4 & 139 & 10 & 153 \\
\hline & \begin{tabular}{|l|} 
Minimum \\
\end{tabular} & 3.6 & 0.35 & 0.33 & 0.33 \\
\hline & \begin{tabular}{|l|} 
Maximum \\
\end{tabular} & 65 & 30 & 3 & 65 \\
\hline & Mean & 20 & 2.1 & 0.88 & 2.5 \\
\hline \multirow[t]{4}{*}{ Beryllium } & Number of samples & 4 & 118 & 9 & 131 \\
\hline & \begin{tabular}{|l|} 
Minimum \\
\end{tabular} & 1.4 & 0.03 & 0.17 & 0.03 \\
\hline & Maximum & 4.2 & 9.1 & 1.7 & 9.1 \\
\hline & Mean & 2.4 & 0.51 & 0.44 & 0.56 \\
\hline \multirow[t]{4}{*}{ Cadmium } & Number of samples & 4 & 133 & 10 & 147 \\
\hline & \begin{tabular}{|l|} 
Minimum \\
\end{tabular} & 0.09 & 0.01 & 0.03 & 0.01 \\
\hline & Maximum & 0.52 & 0.72 & 0.12 & 0.72 \\
\hline & Mean & 0.25 & 0.07 & 0.05 & 0.07 \\
\hline \multirow[t]{4}{*}{ Chlorine } & Number of samples & 4 & 107 & 9 & 120 \\
\hline & \begin{tabular}{|l|} 
Minimum \\
\end{tabular} & 50 & 50 & 50 & 50 \\
\hline & Maximum & 50 & 700 & 50 & 700 \\
\hline & Mean & 50 & 157 & 50 & 146 \\
\hline \multirow[t]{4}{*}{ Chromium } & Number of samples & 4 & 143 & 10 & 157 \\
\hline & Minimum & 14 & 0.81 & 1.7 & 0.81 \\
\hline & Maximum & 19 & 35 & 12 & 35 \\
\hline & Mean & 17 & 4.7 & 5.2 & 5.02 \\
\hline \multirow[t]{4}{*}{ Cobalt } & Number of samples & 4 & 143 & 10 & 157 \\
\hline & \begin{tabular}{|l|} 
Minimum \\
\end{tabular} & 3.2 & 0.28 & 0.71 & 0.28 \\
\hline & Maximum & 9.7 & 11 & 11 & 11 \\
\hline & Mean & 5.8 & 1.8 & 3.9 & 2.01 \\
\hline \multirow[t]{4}{*}{ Lead } & Number of samples & 4 & 143 & 10 & 157 \\
\hline & \begin{tabular}{|l|} 
Minimum \\
\end{tabular} & 2.4 & 0.14 & 0.76 & 0.14 \\
\hline & Maximum & 7.7 & 14 & 7.6 & 14 \\
\hline & \begin{tabular}{|l|} 
Mean \\
\end{tabular} & 5.04 & 2.5 & 2.9 & 2.5 \\
\hline \multirow[t]{4}{*}{ Manganese } & Number of samples & 4 & 143 & 10 & 157 \\
\hline & \begin{tabular}{|l|} 
Minimum \\
\end{tabular} & 15 & 2.7 & 2.5 & 2.5 \\
\hline & Maximum & 85 & 86 & 17 & 86 \\
\hline & Mean & 44 & 16 & 8.3 & 16 \\
\hline \multirow[t]{4}{*}{ Mercury } & Number of samples & 4 & 86 & 10 & 100 \\
\hline & \begin{tabular}{|l} 
Minimum \\
\end{tabular} & 0.14 & 0.02 & 0.02 & 0.02 \\
\hline & Maximum & 0.35 & 3.8 & 0.16 & 3.8 \\
\hline & Mean & 0.26 & 0.21 & 0.07 & 0.20 \\
\hline \multirow[t]{4}{*}{ Nickel } & Number of samples & 4 & 143 & 10 & 157 \\
\hline & \begin{tabular}{|l|} 
Minimum \\
\end{tabular} & 13 & 0.85 & 1.5 & 0.85 \\
\hline & Maximum & 21 & 39 & 9.3 & 39 \\
\hline & Mean & 17 & 5.1 & 6.2 & 5.5 \\
\hline \multirow[t]{4}{*}{ Selenium } & Number of samples & 4 & 136 & 8 & 148 \\
\hline & \begin{tabular}{|l|} 
Minimum \\
\end{tabular} & 1.5 & 0.05 & 0.18 & 0.05 \\
\hline & Maximum & 2.2 & 6.7 & 1.7 & 6.7 \\
\hline & Mean & 1.8 & 1.01 & 0.59 & 1.01 \\
\hline \multirow[t]{4}{*}{ Uranium } & Number of samples & 4 & 139 & 10 & 153 \\
\hline & \begin{tabular}{|l|} 
Minimum \\
\end{tabular} & 1.4 & 0.08 & 0.01 & 0.01 \\
\hline & Maximum & 2.9 & 3.2 & 1.2 & 3.2 \\
\hline & Mean & 2.1 & 0.61 & 0.46 & 0.64 \\
\hline
\end{tabular}


The Upper Wyodak coal in the Gillette coal field is of particular interest for future development, because it is laterally pervasive and reaches a maximum thickness of about $200 \mathrm{ft}(61 \mathrm{~m})$. The Upper Wyodak coal bed also has higher mean gross calorific value $(8,569 \mathrm{Btu} / \mathrm{lb})$, lower mean ash yield (5.8 percent), and lower mean total sulfur content ( 0.46 percent) than most other Wyodak-Anderson coal beds in the Gillette study area (Tables 8 and 10).

Table 10. Comparison of coal quality of the Wyodak-Anderson coal in the Powder River Basin and in the Gillette coalfield (Flores and others, 1999; Ellis and others, 1999), and of the economically extractable coal beds and the Upper Wyodak coal bed in the Gillette coal field. Proximate, ultimate, and heat of combustion values are reported on an as-received basis. Trace elements are reported on a whole-coal and remnantmoisture basis. Btu is British thermal units; MmmfBtu is moist, mineral-matter free Btu; and ppm is parts per million

\begin{tabular}{|l|c|c|c|c|}
\hline \multirow{2}{*}{\begin{tabular}{c}
\multirow{2}{*}{$\begin{array}{c}\text { Coal quality } \\
\text { parameter }\end{array}$} \\
\cline { 2 - 5 }
\end{tabular}} & $\begin{array}{c}\text { Powder River Basin } \\
\text { Wyodak-Anderson coal } \\
\text { from Flores and others, } \\
\begin{array}{c}1999 \\
\text { (weighted mean) }\end{array}\end{array}$ & $\begin{array}{c}\text { Wyodak-Anderson } \\
\text { coal from Ellis and } \\
\text { others, 1999 } \\
\text { (weighted mean) }\end{array}$ & $\begin{array}{c}\text { Coal beds } \\
\text { assessed for } \\
\text { this study } \\
\text { (mean) }\end{array}$ & $\begin{array}{c}\text { Upper Wyodak } \\
\text { coal bed from } \\
\text { this study } \\
\text { (mean) }\end{array}$ \\
\hline Moisture (percent) & 27.66 & 29.16 & 27 & 27 \\
\hline Ash (percent) & 6.44 & 7.05 & 6.01 & 5.80 \\
\hline Total sulfur (percent) & 0.48 & 0.54 & 0.46 & 0.46 \\
\hline $\begin{array}{l}\text { Gross calorific value } \\
\text { (Btu) }\end{array}$ & 8,220 & 7,874 & 8,554 & 8,569 \\
\hline MmmfBtu & 8,820 & 8,581 & 9,211 & 9,193 \\
\hline $\begin{array}{l}\text { Organic sulfur } \\
\text { (percent) }\end{array}$ & --- & 0.37 & 0.32 & 0.32 \\
\hline Pyritic sulfur (percent) & --- & 0.16 & 0.15 & 0.14 \\
\hline Sulfate sulfur (percent) & --- & 0.03 & 0.03 & 0.03 \\
\hline Fixed carbon (percent) & --- & 33.41 & 34.8 & 35.0 \\
\hline $\begin{array}{l}\text { Volatile matter } \\
\text { percent) }\end{array}$ & -- & 30.38 & 31.87 & 31.71 \\
\hline Arsenic (ppm) & 2.6 & 3.3 & 2.5 & 2.1 \\
\hline Mercury (ppm) & 0.13 & 0.11 & 0.20 & 0.21 \\
\hline Selenium (ppm) & 1.1 & 1.0 & 1.01 & 1.01 \\
\hline Uranium (ppm) & 1.3 & 0.98 & 0.64 & 0.61 \\
\hline
\end{tabular}

\section{CONCLUSION}

Coal in the Powder River Basin, specifically the economically extractable coal in the Gillette coal field, is very desirable for future coal production. The beds are generally thick and relatively close to the surface, making it economic to produce the coal through surface mining operations. The Wyodak-Anderson coal in the Powder River Basin and in the Gillette coal field and five economically extractable beds recently studied also low in total sulfur content and ash yields and 
have relatively high gross calorific value, compared with coal from most other coal fields in the U.S. (Flores and others, 1999).

Table 10 shows the quality of coal in the recent study compared with the quality of coal in the Wyodak-Anderson coal zone throughout the Powder River Basin (Stricker and Ellis, 1999) and in the Gillette coal field (Ellis and others, 1999). Wyodak-Anderson coal in the Powder River Basin has relatively low gross calorific value, with a range of 4,580 to $10,560 \mathrm{Btu}$ and a mean of 8,820 Btu. However, the low sulfur content and ash yield for economically extractable coal seams in the Gillette coal field; with a minimum value of 0.13 percent and a mean of 0.46 percent total sulfur and a minimum value of 2.5 percent and a mean of 6.01 percent ash yield (tables 8 and 10); makes it desirable to blend higher quality coal in these coal seams with lower quality coal to meet power plant emissions standards. The Upper Wyodak bed in the recent USGS study is of particular interest for future development, because it is thick, pervasive, and of high quality.

\section{REFERENCES CITED}

Boyd, C.S. and Ver Ploeg, A.J, 1997, Geologic map of the Gillette 30’ x 60' quadrangle, Campbell, Crook and Weston Counties, northeastern Wyoming: Wyoming State Geological Survey Map Series 49, scale 1:100,000.

Bragg, L.J., Oman, J.K., Tewalt, S.J., Oman, C.L., Rega, N.H., Washington, P.M., and Finkelman, R.B., 1994, U.S. Geological Survey Coal Quality (COALQUAL) database: Version 1.3, U.S. Geological Survey Open-File Report 94-205, CD-ROM.

Curry, W.H., 1971, Laramide structural history of the Powder River Basin, Wyoming: Wyoming Geological Association Guidebook, $23^{\text {rd }}$ Annual Field Conference, p. 49-60.

Denson, N.M. and Keefer, W.R., 1974, Map of the Wyodak-Anderson coal bed in the Gillette area, Campbell County, Wyoming: U.S. Geological Survey Miscellaneous Investigations Series Map I-848-D.

Ellis, M.S., Flores, R.M., Ochs, A.M., Stricker, G.D., Gunther, G.L., Rossi, G.S., Bader, L.R., Schuenemeyer, J.H., and Power, H.C., 1999, Gillette coal field, Powder River Basin: geology, coal quality, and coal resources: Chapter PG in Fort Union Coal Assessment Team, 1999, 1999 Resource Assessment of selected Tertiary coal beds and zones in the Northern Rocky Mountains and Great Plains region: U.S. Geological Survey Professional Paper 1625-A, 84 p.

Flores, R.M., 1986, Styles of coal deposition in Tertiary alluvial deposits, Powder River Basin, Montana and Wyoming: Geological Society of America Special Paper 210, p. 79-102.

Flores, R.M., Roberts, S.B., and Perry, W.J., Jr., 1994, Paleocene paleogeography of the Wind River, Bighorn, and Powder River Basins, Wyoming, in Flores, R.M., Mehring, K.T., Jones, R.W., and Beck, T.L., eds., Organics and the Rockies Field Guide, Wyoming State Geological Survey Public Information Circular No. 33, p. 1-16.

Flores, R.M., Ochs, A.M., Stricker, G.D., Roberts, S.B., Ellis, M.S., Keighin, C.W., Murphy, E.C., Cavaroc, V.V., Jr., Johnson, R.C., and Wilde, E.M., 1999, National coal resource assessment non-proprietary data: Location, stratigraphy, and coal quality of selected Tertiary coals in the Northern Rocky Mountains and Great Plains region: U.S. Geological Survey Open-File Report 99-376, CD-ROM.

Fort Union Coal Assessment Team, 1999, 1999 Resource assessment of selected Tertiary coal beds and zones in the Northern Rocky Mountains and Great Plains region: U.S. Geological Survey Professional Paper 1625-A, CD-ROM.

Glass, G.B., 2000, Coal Geology of Wyoming, in Keystone Coal Industry Manual 2000, Chicago, Ill., Intertec Publishing Company, p. 718-738. 
Heffern, E.L. and Coates, D.A., 1997, Clinker-Its occurrence, uses, and effects on coal mining in the Powder River Basin: Wyoming State Geological Survey Public Information Circular 38, p. 151-165.

Keefer, W.R. and Schmidt, P.W., 1973, Energy resources map of the Powder River Basin, Wyoming and Montana: U.S. Geological Survey Miscellaneous Investigations Series Map I-847-A, scale 1:500,000.

Kent, B.H., Berlage, L.J., and Boucher, E.M., 1980, Stratigraphic framework of coal beds underlying the western part of the Recluse 1 x 1/2 degree quadrangle, Campbell County, Wyoming: U.S. Geological Survey Coal Investigations Map C-81C, 2 plates.

Molnia, C.L., Biewick, L.R.H., Blake, Dorsey, Tewalt, S.J., Carter, M.D., and Gaskill, Charlie, 1997, Coal availability in the Hilight 7.5-minute quadrangle, Powder River Basin, Wyoming-A prototype study in a western coal field: U.S. Geological Survey Open-File Report 97-469, $21 \mathrm{p}$.

Osmonson, L.M., Rohrbacher, T.J., Molnia, C.L., and Sullivan, G.L., 2000, Coal recoverability in the Hilight quadrangle, Powder River Basin, Wyoming: a prototype study in a western coal field: U.S. Geological Survey Open-File Report 00-103, 23 p.

Perry, W.J., Jr., and Flores, R.M., 1994, Sequential Laramide deformation and deep gas-prone basins of the Rocky Mountain region, in Dyman, T.S., Rice, D.D., and Wescott, W.A., eds., Geologic Controls of Deep Natural Gas Resources in the U.S.: U.S. Geological Survey Bulletin 2146-E, p. 49-59.

Pierce, Frances Wahl, Johnson, E.A., Molnia, C.L., and Sigleo, W.R., 1990, Cross sections showing coal stratigraphy of the southeastern Powder River Basin, Wyoming: U.S. Geological Survey Miscellaneous Investigations Series Map I-1959-B, 2 plates.

Resource Data International, Inc., 2000, COALdat -Coal Database: Resource Data International, Inc., 1320 Pearl St., Suite 300, Boulder, CO, 80302.

Stricker, G.D. and Ellis, M.S., 1999, Coal quality and geochemistry, Powder River Basin, Wyoming and Montana: Chapter PQ in Fort Union Coal Assessment Team, 1999, 1999 Resource Assessment of selected Tertiary coal beds and zones in the Northern Rocky Mountains and Great Plains region: U.S. Geological Survey Professional Paper 1625-A, $27 \mathrm{p}$.

U.S. Environmental Protection Agency, 1996, Standards of performance for new stationary sources, 40CFR, Part 60.43, Standards for sulfur dioxide: U.S. Environmental Protection Agency, $27 \mathrm{p}$.

Wood, G.H., Jr., Kehn, T.M., Carter, M.D., and Culbertson, W.C., 1983, Coal resource classification system of the U.S. Geological Survey: U.S. Geological Survey Circular 891, 65 p. 